INFO ARTIKEL

Riwayat Artikel:

Diterima : 15 Mei 2018

Disetujui : 20 Agustus 2018

\title{
PENDIDIKAN
}

\section{PENGARUH PRAKTIK PERCOBAAN KUALITAS AIR TERHADAP HASIL BELAJAR GEOGRAFI SISWA KELAS X SMA AISYIYAH 1 PALEMBANG TAHUN AJARAN 2018/2019}

\section{Septian Kurnia}

Sekolah Menengah Atas Aisyiyah 1 Palembang

$(\bowtie)$ septiangeografi17@gmail.com

\begin{abstract}
ABSTRAK
Penelitian ini berjudul Pengaruh praktik percobaan kualitas air terhadap hasil belajar geografi siswa kelas X di SMA Aisyiyah 1 Palembang dilatar belakangi kurangnya motivasi siswa di dalam kelas dengan model pembelajaran konvensional yang diterapkan oleh guru di sekolah, sehingga mempengaruhi hasil belajar siswa tersebut. Dengan permasalahan ini membuat peneliti mencari suatu cara yang tepat untuk mengatasi hal tersebut salah satunya dengan melibatkan siswa langsung dalam proses pembelajaran praktik percobaan kualitas air. Penelitian ini bertujuan untuk mengetahui hasil belajar geografi siswa kelas X di SMA Aisyiyah 1 Palembang tahun ajaran 2018/2019 dengan menggunakan praktik percobaan kualitas air ini. Melalui metode kuantitatif dengan teknik simple random sampling peneliti dapat membedakan kelas eksperimen dan kelas kontrol. Dengan keseluruan populasi penelitian ini adalah seluruh siswa kelas X IPS SMA Aisyiyah 1 Palembang yang berjumlah seluruhnya 95 siswa. Sampel penelitian ini kelas X IPS 2 sebagai kelas eksperimen dengan jumlah 64 siswa dan X IPS 1 sebagai kelas kontrol dengan jumlah 32 siswa. Teknik pengumpulan data menggunakan teknik tes dan dokumentasi. Teknik analisis data menggunakan Uji-t. Berdasarkan analisis data mengenai hasil belajar siswa melalui Uji-t maka diperoleh nilai $t_{\text {hitung }}=18,1$ sedangkan $t_{\text {tabel }}=1,99$. Dari hasil perhitungan didapat bahwa $t_{\text {hitung }} \geq t_{\text {tabel }}$ maka Ha diterima dengan nilai rata-rata kelas eksperimen 79,7 dan kelas kontrol 67. Dapat disimpulkan ada pengaruh praktik percobaan kualitas air terhadap hasil belajar geografi siswa kelas X di SMA Aisyah 1 Palembang.
\end{abstract}

Kata kunci: Praktik Percobaan, Kualitas Air, Hasil Belajar.

\section{PENDAHULUAN}

Kemajuan pendidikan sangat besar pengaruhnya terhadap perkembangan kehidupan masyarakat. Seperti yang telah dicanangkan oleh pemerintah dalam Undang-Undang Nomor 20 Tahun 2003 Pasal 3 tentang Sistem Pendidikan Nasional yang menyebutkan bahwa, pendidikan nasional berfungsi untuk mengembangkan kemampuan dan membentuk watak serta peradaban bangsa yang bermartabat dalam rangka mencerdaskan kehidupan bangsa, bertujuan untuk berkembangnya potensi peserta didik agar menjadi manusia yang beriman dan bertaqwa kepada Tuhan Yang Maha Esa, berahlak mulia, sehat, berilmu, cakap, kreatif, mandiri, dan menjadi warga negara yang demokratis serta bertanggung jawab. Pendidikan menjadi faktor yang sangat penting dan mempengaruhi suatu kemajuan bangsa. Hal ini dapat dibuktikan ketika berkaca pada beberapa negara maju di dunia, pada dasarnya mereka 
memiliki sebuah sistem pendidikan yang tergolong sangat baik.

Pendidikan merupakan sebuah kebutuhan dan kewajiban yang senantiasa harus dimiliki setiap manusia. Pada saat ini terutama di negara Indonesia sering mendapati dan mengalami kendala-kendala terutama pada guru sebagai tenaga pengajar dan pendidik generasi penerus bangsa. Salah satu hal yang sering ditemui dilapangan ialah rendahnya hasil belajar siswa. Hal ini disebabkan oleh cara belajar yang monoton serta guru menjadi narasumber yang utama di dalam kelas. Oleh karena itu peran seorang guru sangat dituntut untuk mencerdaskan dan mendidik anak bangsa sesuai dengan pembukaan UUD 1945 pada alinea ke empat, yang salah satunya menyerukan kepada para tenaga pendidik untuk mencerdaskan kehidupan bangsa. Sekolah merupakan tempat warga negara Indonesia memperoleh pendidikan berkualitas yang di dalamnya terdapat suatu kegiatan pembelajaran, dalam proses pembelajaran guru juga dituntut harus memiliki strategi, model dan metode yang bervariasi agar siswa dapat belajar secara efektif.

Berdasarkan observasi di lapangan menunjukkan bahwa hasil belajar siswa belum menunjukkan hasil yang maksimal, menurut hasil wawancara dengan narasumber yaitu guru mata pelajaran geografi di SMA Aisyiyah 1 Palembang mengungkapkan bahwa (1) guru sudah menggunakan beberapa metode namun metode ceramah masih dominan, (2) siswa merasa kurang diikutsertakan dalam proses pembelajaran, (3) pembelajaran geografi dengan praktik percobaan jarang dilakukan, (4) kurikulum 2013 belum dijalankan secara efektik.

Kurikulum 2013 saat ini menuntut para guru untuk lebih melibatkan siswanya dalam proses pembelajaran di dalam kelas, salah satu metode yang dapat dimanfaatkan oleh guru ialah menerapkan metode praktik di dalam kelas, salah satunya praktik percobaan kualitas air. Praktik merupakan suatu upaya untuk meningkatkan keterampilan siswa/i dengan menggunakan berbagai metode yang sesuai dengan keterampilan yang diberikan dan peralatan yang digunakan sesuai dengan mata pelajaran yang bersangkutan.
Simanjuntak dalam (Syahrowiyah, 2016) menjelaskan bahwa metode ini memberikan jalan kepada para peserta didik untuk menerapkan, menguji dan menyesuaikan teori dengan kondisi sesungguhnya melalui paktik atau kerja, inilah peserta praktik atau latihan akan mendapatkan pelajaran yangsangat baik untuk mengembangkan dan menyempurnakan keterampilan yang diperlukan.Selain itu, praktik juga merupakan suatu proses pendidikan yang berfungsi membimbing siswa/i secara terarah untuk dapat melakukan suatu ketrampilan tertentu. Praktik juga senantiasa dapat memberikan kesempatan siswa/i untuk terlibat dan berinteraksi secara langsung dengan objek yang telah ditentukan sertadapat memberikan pengalaman langsung pada siswa/i.

Penjelasan tersebut juga didukung oleh hasil penelitian yang dilakukan oleh Dale dalam (Daryanto \& Tarno, 2017) bahwa orang akan mengingat: $20 \%$ dari apa yang mereka dengar, $30 \%$ dari apa yang mereka lihat, 50\% dari apa yang mereka lihat dan dengar dan $80 \%$ dari apa yang mereka dengar, lihat dan lakukan.

Utomo, 2013; dan Pupuh dalam (Syahrowiyah, 2016) mengungkapkan bahwa metode praktik adalah suatu metode dengan memberikan materi pendidikan baik menggunakan alat atau benda, seperti diperagakan, dengan harapan anak didik menjadi jelas dan mudah sekaligus dapat mempraktikkan materi yang dimaksud dan suatu saat di masyarakat. Dengan melakukan pelaksanaan secara nyata dari teori metode praktik juga merupakan suatu upaya untuk meningkatkan keterampilan siswa/i dengan menggunakan berbagai metode yang sesuai dengan keterampilan yang diberikan dan peralatan yang digunakan sesuai dengan mata pelajaran yang bersangkutan.

Selain itu, pembelajaran praktik juga merupakan suatu proses pendidikan yang berfungsi membimbing siswa/i secara terarah untuk dapat melakukan suatu ketrampilan tertentu. Metode praktik juga senantiasa dapat memberikan kesempatan siswa/i untuk terlibat dan berinteraksi secara langsung dengan objek yang telah ditentukan sertadapat memberikan pengalaman langsung pada siswa/i. 
Wallace dalam (Dariyati, 2016) menjelaskan bahwa efektifnya praktik tergantung pada bagaimana peserta didik melakukan refleksi dengan mengkaitkan antara pengetahuan dan pengalaman serta praktik, sehingga dapat memperbaiki pembelajaran lebih lanjut. Kemampuan melakukan refleksi dari praktik yang didasarkan pada pengalaman dan pengetahuan menentukan pencapaian kompetensi profesional. Diharapkan selama praktik, peserta didik mampu melihat, mengamati, memahami, membandingkan dan memecahkan suatu masalah saat kegiatan praktik dilaksanakan.

Rustaman dalam Murjainah dan Utomo (2018) menyatakan bahwa kegiatan praktikum dapat dikelompokkan dalam tiga bentuk, yaitu:

a) Bentuk praktikum latihan: praktikum yang dimaksudkan untuk mengembangkan keterampilan dasar, misalnya keterampilan mengamati, keterampilan mengukur, dan keterampilan menggunakan mikroskop.

b) Bentuk praktikum bersifat investigasi (penyelidikan): praktikum yang dimaksudkan untuk mengembangkan kemampuan siswa untuk bertindak sebagai ilmuwan, misalnya bagaimana menganalisis masalah dan memecahkannya. Melalui kegiatan praktikum ini mahasiswa memperoleh pengalaman mengidentifikasi masalah nyata yang dirasakannya, merumuskan masalah tersebut secara operasional, merancang cara terbaik untuk memecahkan masalahnya, melakukan percobaan/pengamatan, dan menganalisis dan mengevaluasi hasilnya.

c) Bentuk praktikum bersifat memberi pengalaman: praktikum ini dimaksudkan untuk mendukung pemahaman siswa terhadap konsepkonsep yang terkait. Kontribusi praktikum dalam meningkatkan pemahaman terhadap materi pelajaran dapat terwujud apabila siswa diberi pengalaman untuk mengindera fenomena alam dengan segenap inderanya.

Kualitas air adalah kondisi fisik, kimiawi, biologis, radiologi air di permukaan dan di dalam bumi. Kualitas air di setiap daerah tidaklah selalu sama, tergantung dari faktor-faktor yang mempengaruhinya seperti faktor geografis dan faktor manusia. Faktor geografis disebut juga faktor alami meliputi batuan, tanah, vegetasi dan iklim, sedangkan faktor buatan yang banyak disebabkan oleh manusia meliputi pupuk, limbah pertanian, insektisida, limbah domestik, serta limbah industri.

Kualitas air ditentukan berdasarkan keadaan air dalam keadaan normal disebut sebagai air yang mengalami pencemaran, atau disebut air terpolusi, air dengan kualitas baik harus bebas dari senyawa pencemar toksik, bebas bakteri (mikroorganisme), tidak berasa, dan tidak berwarna (Situmorang, 2017). adapun Kualitas Air Secara Fisik;

a) Suhu Air

Suhu air merupakan parameter penting untuk mengetahui lebih jauh parameter kimiawi yang lain seperti $\mathrm{pH}$, Dissoleved Oxygen, dan DHL. Suhu air berbeda dengan suhu udara karena air memiliki kapasitas menyimpan panas lebih tinggi dibandingkan udara. Air juga akan mempengaruhi suhu udara melalui proses, evaporasi, transpirasi, dan kondensasi. Aktivitas manusia dari keperluan rumah tangga, terutama di dalam indrustri seperti pada pengoprasian peralatan membutuhkan air sebagai bahan pendingin mesin-mesin, sehingga suhu air buangan yang berasal dari indrustri menjadi lebih panas bila dibandingkan dengan suhu air yang terdapat dilingkungan asalnya (Situmorang, 2017).

b) Warna

Warna dalam air disebabkan oleh zat-zat yang terlarut di dalam air tersebut, perubahan warna dapat disebabkan oleh terbentuknya warna dari hasil buangan sebagai akibat proses kimia yang dapat menghasilkan zat berwarna, atau berasal dari degradasi senyawa-senyawa organik melarut dalam air. Perubahan warna air dapat dipergunakan sebagai pertanda terjadinya pencemaran air, dan air yang terlihat jernih tidak selamanya bebas dari bahan pencemar (Situmorang, 2017).

c) $\mathrm{Bau}$

Bau merupakan aroma tidak sedap yang dikeluarkan oleh air. Masuknya limbah buangan ke dalam air dapat juga menghasilkan dan rasa yang tidak menyenangkan. Sumber bau yang terdapat pada air dapat berupa gas atau senyawa kimia yang berasal dari bahan buangan indrustri (Situmorang, 2017). 
Adapun kualitas air secara kimia;

a) $\mathrm{pH}$

Tingkat keasaman air atau sering disebut sebagai kekuatan asam $(\mathrm{pH})$ termasuk untuk parameter untuk kualitas air. Air yang belum terpolusi biasannya memilki tingkat keasaman berada pada skala pH $(6,0-8,0)$ Menurut Situmorang (2017: 51). Air murni biasanya mempunyai $\mathrm{pH}=7,0$ pada suhu $25^{\circ} \mathrm{C}$. Kebanyakan airtanah mempunyai $\mathrm{pH}$ antara 5,0 sampai 8,0. berikut merupakan klasifikasi indikator kualitas air berdasarkan $\mathrm{pH}$ :

1. $\mathrm{pH}$ air sangat tinggi $(>8,5)$ biasanya disebabkan oleh banyaknya sodium carbonatebicarbonate yang terlarut.pH air setengah tinggi $(7,0-8,5)$ biasanya disebabkan oleh tingginya bicarbonate yang terlarut.

2. $\mathrm{pH}$ air setengah rendah $(4,0-7,0)$ disebabkan oleh kecilnya mineral-mineral asam dari sulfide atau asam organic

3. $\mathrm{pH}$ air sangat rendah $(<4,0)$ disebabkan oleh adanya asam bebas yang terlarut $\mathrm{pH}$ air diukur langsung di lapangan bersamaan dengan saat pengambilan contoh air, karena dengan dibawanya sampel air di laboratorium akan terjadi perubahan $\mathrm{pH}$.

Menurut (Susanto, 2015) mengemukakan bahwa yang dimaksud dengan hasil belajar siswa adalah kemampuan yang diperoleh anak setelah melalui kegiatan belajar. Dipertegas lagi oleh Nawawi dalam (Susanto, 2015) yang menyatakan bahwa hasil belajar dapat diartikan sebagai tingkat keberhasilan siswa dalam mempelajari materi pelajaran di sekolah yang dinyatakan dalam skor yang diperoleh dari hasil tes mengenai sejumlah materi pelajaran tertentu. Berdasarkan pengertian hasil belajar di atas dapat disimpulkan bahwa hasil belajar adalah tingkat keberhasilan siswa dalam proses belajar mengajar yang diperoleh dari hasil tes mengenai sejumlah materi pelajaran.

\section{METODOLOGI PENELITIAN}

Pada penelitian ini peneliti menggunakan metode penelitian eksperimen. Dalam penelitian ini yang diambil dari populasi tertentu dikelompokan secara keseluruhan menjadi dua kelompok yaitu kelompok eksperimen dan kelompok kontrol. Kelompok eksperimen diberikan perlakuan praktik percobaan kualitas air dalam jangka waktu 1 x 3 jam pelajaran selama 2 minggu, lalu kedua kelompok dikenai pengukuran yang sama. Pada kelas X IPS 2 akan diterapkan penggunaan praktik percobaan kualitas air (kelas eksperimen) dan pada kelas X IPS 1 diterapkan sumber belajar tanpa menggunakan praktik percobaan kualitas air atau menggunakan metode ceramah (kelas kontrol).

Adapun rancangan perlakuan pelaksanaan praktik dikelas eksperimen adalah sebagai berikut:

1. Bagi siswa menjadi 2 kelompok agar mudah untuk melakukan praktik percobaan dilapangan.

2. Sebelumnya, kedua kelompok tersebut telah diberikan instruksi masing-masing 1 membawa air tercemar dan 1 air bersih.

3. Guru membagikan lembar kerja pengukuran kualitas air.

4. Kemudian tempatkan kedua objek tersebut di meja praktik.

5. Setelah itu guru melibatkan siswa secara langsung dalam melakukan pengukuran kualitas air secara fisika (warna, bau dan suhu) serta kimia yaitu $\mathrm{pH}$ dengan menggunakan $\mathrm{pH}$ meter.

6. Selanjutnya ketika siswa selesai melakukan pengukuran kualitas air guru menjelaskan apa yang saja hasil dari pengukuran kualitas air.

Hipotesis dalam penelitian ini sebagai berikut: Ha : Ada Pengaruh Praktik Percobaan Kualitas Air Terhadap Hasil Belajar Geografi Siswa Kelas $\mathrm{X}$ di SMA Aisyiyah 1 Palembang Tahun Pelajaran 2018/2019.

Ho: Tidak ada Pengaruh Praktik Percobaan Kualitas Air Terhadap Hasil Belajar Geografi Siswa Kelas X di SMA Aisyiyah 1 Palembang Tahun Pelajaran 2018/2019.

Kriteria penguji hipotesis dalam penelitian ini sebagai berikut:

Terima Ha, Jika $t_{\text {hitung }}>t_{\text {tabel }}$ Ho ditolak

Terima Ho, Jika $t_{\text {hitung }}<t_{\text {tabel }}$ Ha ditolak

Populasi dalam penelitian ini adalah seluruh siswa/i kelas X SMA Aisyiyah 1 Palembang yang berjumlah 95 orang siswa. Dengan menggunakan teknik pengambilan sampel secara acak (random sampling) didapat sampel berjumlah 64 orang dimana Kelas X IPS 1 dan X IPS 2 masing-masing sebanyak 32 orang siswa. 
Teknik pengumpulan data pada penelitian ini menggunakan tes dan dokumentasi. Tes dalam penelitian ini adalah instrumen yang digunakan untuk mengumpulkan data tentang hasil belajar Geografi kelas X di SMA Aisyiyah 1 Palembang, sebelum tes diberikan, siswa terlebih dahulu mengikuti pembelajaran pokok bahasan mengenai materi dinamika hidrosfer dan dampaknya bagi kehidupan, evaluasi dalam penelitian ini menggunakan soal pilihan ganda yang berjumlah 20 soal.

\section{HASIL DAN PEMBAHASAN}

Dari tes hasil belajar yang telah dilakukan peneliti pada kelas eksperimen dan kelas kontrol didapat nilai sebagai berikut:

Tabel 1 Data Nilai Tes Kelas Eksperimen aan Kelas Kontrol

\begin{tabular}{clccc}
\hline No & Kelas & $\begin{array}{c}\text { Nilai } \\
\text { Terti } \\
\text { nggi }\end{array}$ & $\begin{array}{c}\text { Nilai } \\
\text { Terend } \\
\text { ah }\end{array}$ & $\begin{array}{c}\text { Nilai } \\
\text { rata - } \\
\text { rata }\end{array}$ \\
\hline 1 & Eksperimen & 95 & 60 & 79,5 \\
\hline 2 & Kontrol & 85 & 40 & 67,1 \\
\hline \multicolumn{4}{l}{ Sumber: pengolahan data primer 2018}
\end{tabular}

Tabel di atas menunjukkan bahwa nilai ratarata kelas eksperimen lebih tinggi dari pada kelas kontrol. Dengan data yang didapat agar dapat diketahui pengaruh praktik percobaan air terhadap hasil belajar geografi tentu dilakukan uji normalitas, uji homogenitas dan uji hipotesis. Hasil analisis data ini dapat dilihat dari uraian berikut.

1. Uji Normalitas

Dari data rata - rata nilai modus dan simpangan baku, dapat dicari kemiringan kurva dengan menggunakan rumus Karl Person sebagai berikut:

$$
\begin{aligned}
k m & =\frac{-x-M o}{S} \\
k m & =\frac{79,7-75,1}{7,73} \\
k m & =\frac{4,6}{7,73} \\
k m & =0,59
\end{aligned}
$$

Kemudian melakukan uji normalitas pada kelas kontrol sebagai berikut:

a. $\quad$ Rentang $=45$ b. $\quad$ Banyak kelas interval $=5,95$ dibulatkan menjadi 6 (6 merupakan banyak kelas interval)

c. $\quad$ Panjang kelas interval $=7,5$ dibulatkan menjadi 8 (8 merupakan rentang antara 4047)

d. Membuat tabel distribusi frekuensi

Tabel 2 Daftar Distribusi Frekuensi Kelas Kontrol

\begin{tabular}{cccccc}
\hline Interval & $\boldsymbol{f}_{\boldsymbol{I}}$ & $\boldsymbol{x}_{\boldsymbol{1}}$ & $\boldsymbol{f}_{\boldsymbol{l} . \boldsymbol{x}_{\boldsymbol{I}}}$ & $\boldsymbol{x}_{\boldsymbol{I}}{ }^{2}$ & $\boldsymbol{f}_{1 . \boldsymbol{x}_{\boldsymbol{I}}{ }^{2}}$ \\
\hline $40-47$ & 1 & 43,5 & 43,5 & 1892,25 & 1892,25 \\
\hline $48-55$ & 1 & 51,5 & 51,5 & 2652,25 & 2652,25 \\
\hline $56-63$ & 9 & 59,5 & 535,5 & 3540,25 & 31862,25 \\
\hline $64-71$ & 11 & 67,5 & 742,5 & 4556,25 & 50118,75 \\
\hline $72-79$ & 8 & 75,5 & 604 & 5700,25 & 45602 \\
\hline $80-87$ & 2 & 83,5 & 167 & 6972,25 & 13944,5 \\
\hline$\sum$ & 32 & 381 & 2144 & 25313,5 & 146121,5 \\
\hline
\end{tabular}

Sumber: pengolahan data primer 2018

Tabel distribusi frekuensi hasil belajar siswa kelas kontrol

a. Nilai rata - rata kelas kontrol $=67$

b. Modus $\rightarrow M_{0}=63,9$

c. Simpangan Baku (Standar Deviasi)

$S=8,92$

Dari data rata - rata nilai modus dan simpangan baku, dapat dicari kemiringan kurva dengan menggunakan rumus Karl Person sebagai berikut :

$$
\begin{aligned}
k m & =\frac{x-M o}{S} \\
k m & =\frac{67-63,9}{8,92} \\
k m & =\frac{3,1}{8,92} \\
k m & =0,34
\end{aligned}
$$

Dari perhitungan kemiringan kurva yang menggunakan rumus Karl Person, nilai km di dapat pada kelas eksperimen adalah 0,59 sedangkan kelas kontrol adalah 0,34 . dan keduanya terletak di antara -1 dan 1 maka data hasil tes pada kelas eksperimen dan kelas kontrol berdistribusi normal.

2. Uji Homogenitas

Uji Homogenitas data pada penelitian ini menggunakan "Uji bartlett" dengan taraf nyata $\alpha=$ 
0,05 menggunakan tabel $\mathrm{F}$ dengan langkah-langkah sebagai berikut:

1) Masukkan angka-angka statistik untuk pengujian homogenitas pada tabel Bartlett.

Tabel 3 Uji Homogenitas dengan Uji Bartlett

\begin{tabular}{|c|c|c|c|c|c|}
\hline Sampel & $\begin{array}{l}\text { dk } \\
= \\
(\mathbf{n}- \\
\text { 1) }\end{array}$ & $\mathbf{S}_{1}{ }^{2}$ & $\begin{array}{l}\log \\
\mathrm{S}_{1}{ }^{2}\end{array}$ & $\begin{array}{c}\text { (dk). } \\
\text { Log } \\
\mathbf{S}_{1}{ }^{2}\end{array}$ & dk. $S_{1}{ }^{2}$ \\
\hline $\begin{array}{l}\text { Kelas X } \\
\text { IPS } 2\end{array}$ & 31 & 7,73 & 0,88 & 27,2 & 239,63 \\
\hline $\begin{array}{l}\text { Kelas X } \\
\text { IPS } 1\end{array}$ & 31 & 8,92 & 0,95 & 29,4 & 276,52 \\
\hline Jumlah & 62 & 16,84 & 1,83 & 56,6 & 516,15 \\
\hline
\end{tabular}

Sumber: Pengolahan data primer Tahun 2018

2) Menghitung varians gabungan dari kedua sampel.

$$
\begin{aligned}
& S^{2}=\frac{(n 1-1) S_{1^{2}}+(n 2-1) S_{2^{2}}}{n 1+n 2-2} \\
& S^{2}=\frac{(31 \times 7,73)+(31 \times 8,92)}{(32)+(32-1)} \\
& S^{2}=\frac{239,63+276,52}{62} \\
& S^{2}=\frac{516,15}{62} \\
& S^{2}=8,308
\end{aligned}
$$

1. Menghitung $\log \mathrm{S}^{2}=\log 8,308=0,919$

2. Menghitung nilai $B=\left(\log S^{2}\right) \cdot \sum\left(n_{i}-1\right)=0,919$ x $62=56,97$

3. Menghitung nilai $x^{2}{ }_{\text {hitung }}=(\operatorname{In} 10)[\mathrm{B}-\Sigma(\mathrm{dk})$ $\left.\log \mathrm{S}_{\mathrm{i}}^{2}\right]$

$=(2.303) \times[56,97-56,6]$

$=2.303 \times 0,37=0,852$

$x^{2}$ hitung $=0,852$

$x^{2}{ }_{\text {tabel }}=3,841$

sehingga dapat ditulis $0.852<3,841$. syarat homogenitas yaitu;

Jika $x^{2}$ hitung $\geq x^{2}$ tabel, berarti tidak homogen.

Jika $x^{2}{ }_{\text {hitung }} \leq x^{2}{ }_{\text {tabel}}$, berarti homogen.
Ternyata $x^{2}{ }_{\text {hitung }}<x^{2}{ }_{\text {tabel }}$ atau $0,852<3,841$, maka dapat disimpulkan sampel berasal dari populasi yang sama atau homogen .

\section{Uji Hipotesis}

Dari perhitungan sebelumnya, diperoleh nilai rata-rata dan simpangan baku untuk kelas eksperimen dan kelas kontrol dapat ditunjukkan pada tabel di bawah ini :

Tabel 4 Nilai Rata-Rata dan Simpangan Baku

\begin{tabular}{cccccc}
\hline \multicolumn{3}{c}{ Kelas Eksperimen } & \multicolumn{3}{c}{ Kelas Kontrol } \\
\hline $\bar{X}{ }_{1}$ & $\mathrm{~S}_{1}{ }^{2}$ & $n_{1}$ & $\bar{X}$ & $\mathrm{~S}_{1}{ }^{2}$ & $n_{2}$ \\
\hline 79,7 & 7,73 & 32 & 67 & 8,92 & 31
\end{tabular}

Sumber: Pengolahan data primer Tahun 2018

Setelah dinyatakan distribusi normal dan sampel dari populasi yang sama atau homogen maka dilakukan pengujian hipotesis dengan menggunakan statistik $\mathrm{t}$ (uji t) dengan rumus sebgai berikut :

a) Menentukan harga $t_{\text {hitung }}$

$$
\begin{aligned}
& t=\frac{\left(\overline{X_{1}}-\overline{X_{2}}\right)}{S_{p} \sqrt{\left(\frac{1}{n_{1}}\right)+\left(\frac{1}{n_{2}}\right)}} \\
& S_{p}=\sqrt{\frac{\left(n_{1}-1\right) s_{1}^{2}+\left(n_{2}-1\right) s_{2}^{2}}{n_{1}+n_{1}-2}} \\
& S_{p}=\sqrt{\frac{(32-1)(7,73)+(31-1)(8,92)}{32+31-2}} \\
& S_{p}=\sqrt{\frac{239,63+267,6}{61}} \\
& S_{p}=\sqrt{\frac{507,23}{61}} \\
& S_{p}=\sqrt{8,3152} \\
& S_{p}=2,8
\end{aligned}
$$

maka, 


$$
\begin{aligned}
& t=\frac{\left(\overline{X_{1}}-\overline{X_{2}}\right)}{S_{p} \sqrt{\left(\frac{1}{n_{1}}\right)+\left(\frac{1}{n_{2}}\right)}} \\
& t=\frac{(79,7-67)}{2,8 \sqrt{\frac{1}{32}+\frac{1}{31}}} \\
& t=\frac{12,7}{2,8 \sqrt{0,031+0,032}} \\
& t=\frac{12,7}{2,8(0,25)}=\frac{12,7}{0,7}=18,1
\end{aligned}
$$

b) Menentukan harga $t_{\text {tabel }}$

Berdasarkan Menetukan kaidah pengujian dengan taraf signifikannya $\alpha=(0,05)$

$$
\mathrm{dk}=\mathrm{n}-2=64-2=62
$$

Untuk mencari tabel adalah:

$$
\begin{aligned}
& \mathrm{dk}=\mathrm{n} 1+\mathrm{n} 2-2 \\
& \mathrm{dk}=32+32-2 \\
& \mathrm{dk}=62
\end{aligned}
$$

Jadi $t_{\text {hitung }} 18,1$ sedangkan $t_{\text {tabel }}$ tidak terdapat dalam distribusi $t$, maka harus ditentukan Interpolasinya dengan rumus:

Dimana:

Nilai d.k. 62 tidak terdapat pada d.k 70, nilai $\mathrm{t}$ untuk d.k 60 pada tabel 1,670 sedangkan nilai $t$ untuk d.k 70 adalah 1,666. maka selisih nilai $t$ adalah sebagai berikut:

Nilai $r-t_{\text {value }}=2,0003-1,9944=0,0059$

Sedangkan selisih nilai dua d.k terdekat adalah 70 $60=10$

Maka :

$$
\begin{aligned}
& I=\frac{r-t_{\text {value }}}{r-d . f .} x(d . f .- \text { lowest.d.f }) \\
& I=\frac{0,00059}{10} x(62-60) \\
& I=0,00059 \times 2 \\
& I=0,00118
\end{aligned}
$$

Nilai t untuk d.k $62=$ nilai d.k 60 - I

$=2,0003-0,00118$

$=1,99912$

Hasil yang diperoleh menunjukkan nilai $\mathrm{t}_{\text {hitung }}$ $=18,1$ dan $t_{\text {tabel }}=1,99$ Berdasarkan kriteria pengujian hipotesis terlihat bahwa $t_{\text {hitung }}>\mathrm{t}_{\text {tabel }}$ yaitu 18,1> 1,99. Sehingga Ha diterima. Dan hipotesis yang diajukan berbunyi Pengaruh Praktik Percobaan Kualitas Air terhadap Hasil Belajar
Geografi Siswa Kelas X di SMA Aisyiyah1 Palembang dapat diterima kebenarannya.

Penelitian ini dilakukan selama 2 (dua) minggu dengan 8 (delapan) kali pertemuan. Dalam penelitian ini kelas X IPS 2 diberikan perlakuan pembelajaran menggunakan praktik percobaan kualitas air dengan 3 (tiga) kali pertemuan, sedangkan pada kelas X IPS 1 diberikan perlakuan pembelajaran ceramah dengan 3 (tiga) kali pertemuan. Untuk pertemuan ke 4 (empat) dilakukan tes untuk mengetahui hasil belajar terhadap kedua kelompok kelas tersebut.

Dari hasil penelitian menunjukkan kelas X IPS 2 lebih baik dari pada kelas X IPS 1. Dapat dilihat dari nilai rata-rata hasil belajar siswa yang diajarkan menggunakan praktik percobaan kualitas air sebesar 79,7 dan nilai rata-rata hasil belajar siswa yang di ajarkan menggunakan model pembelajaran ceramah sebesar 67. Setelah pengujian normalitas dan homogenitas data dilakukan, maka data yang peneliti ambil berasal dari populasi yang berditribusi normal dan varians dalam penelitian bersifat homogen, maka untuk tahap berikutnya melakukan pengujian hipotesis dengan menggunakan statistik parametris yaitu menggunakan rumus uji-t. Dari analisis data pokok bahasan hidrologi dengan menerapkan praktik percobaan kualitas air diperoleh $\mathrm{t}$ hitung $=18,1$ atas dasar taraf signifikan 0,05 untuk dk 62, diperoleh $\mathrm{t}$ tabel $=1,99$, maka $\mathrm{t}$ hitung $>\mathrm{t}$ tabel yaitu $18,1>$ 1,99. Berdasarkan kriteria pengujian hipotesis maka Ho ditolak dan Ha diterima, hal ini berarti bahwa ada pengaruh praktik percobaan kualitas air terhadap hasil belajar geografi siswa kelas $\mathrm{X}$ di SMA Aisyiyah 1 Palembang tahun pelajaran 2018/2019.

\section{SIMPULAN}

Dilihat dari hasil analisis data dan pembahasan mengenai praktik percobaan kualitas air terhadap hasil belajar geografi siswa kelas $\mathrm{X}$ di SMAAisyiyah 1 Palembang dapat disimpulkan bahwa hasil analisis data rata-rata hasil belajar siswa kelas eksperimen sebesar 79,7 sedangkan kelas kontrol rata-rata hasil belajar siswa sebesar 67. berdasarkan hasil uji-t diperoleh $t_{\text {hitung }}=18,1$ kemudian dibandingkan dengan $t_{\text {tabel }}=1,99$, maka $t_{\text {hitung }}>t_{\text {tabel }}$ yaitu $18,1>1,99$ maka hipotesis yang 
menyatakan terdapat pengaruh praktik percobaan kualitas air terhadap hasil belajar geografi siswa kelas X di SMA Aisyiyah1 Palembang Tahun Pelajaran 2018/2019 diterima(terima Ha). Jadi dengan demikian,

\section{DAFTAR PUSTAKA}

Dariyati, Marhaeni, \&Widiartini. (2016). "Pengaruh Pembelajaran Praktik Berbantuan Media Audio Terhadap KemampuanMotorik Dan Motivasi Belajar Siswa SMP Di SLBA Negeri Denpasar Tahun Pelajaran 2014/2015”. Jurnal Universitas Ganesha Singaraja, diakses 11 Januari 2018.

Daryanto \& Tarno. (2017). Pendidikan Orang Dewasa. Yogyakarta: Gava Media.

Murjainah, M dan Budi Utomo. (2018). Pengaruh Praktikum Sistem Informasi Geografis Terhadap Kemampuan Mahasiswa Pendidikan Geografi Dalam Membuat Peta Berbasis Arcgis. DOI : 10.31851/swarnabhumi .v3i1.1706. https://jurnal.univpgri-palembang. ac.id/index.php/swarna/article/view/1707.
Jurnal Swarnabhumi P-ISSN 2548-5563 and E-ISSN number 2622-2701. Diakses 11 Juni 2018

Situmorang. (2017). Kimia Lingkungan. Depok: Rajawali Pers.

Susanto, Ahmad. (2015). Teori Belajar dan Pembelajaran di Sekolah. Jakarta: Prenadamedia Grup

Syahrowiyah. (2016). "Pengaruh Metode Pembelajaran Praktik Terhadap Motivasi Dan Hasil Belajar Pendidikan Agama Islam Siswa Kelas IV Sekolah Dasar”. Jurnal Ilmiah Pendidikan, diakses 11 Januari 2018.

Utomo, Budi. (2013). Perbedaan Hasil Belajar Geografi Antara Siswa Yang Diajar Menggunakan Model Jigsaw Dengan Model Think Pair Share Kelas Xi Di SMA N 2 OKU. Prosiding Seminar Pendidikan Nasional Palembang. Universitas PGRI Palembang: 898-912. (online). https://jurnal.univpgripalembang.ac.id/index.php/prosiding/article/ download/1023/870, diakses 11 Januari 2018. 